\title{
NOVEMBER 1971
}

ELEVENTH YEAR - No. 128

\section{international review of the red cross}

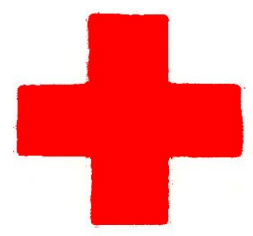

INTER ARMA CARITAS

GENEVA

INTERNATIONAL COMMITTEE OF THE RED CROSS FOUNDED IN 1863 


\section{INTERNATIONAL COMMITTEE OF THE RED CROSS}

MARCEL A. NAVILLE, President (member since 1967)

JEAN PICTET, Doctor of Laws, Chairman of the Legal Commission, Vice-President (1967)

HARALD HUBER, Doctor of Laws, Federal Court Judge, Vice-President (1969)

PAUL RUEGGER, Ambassador, President of the ICRC from 1948 to 1955 (1948)

GUILLAUME BORDIER, Certificated Engineer E.P.F., M.B.A. Harvard, Banker (1955)

HANS BACHMANN, Doctor of Laws, Winterthur Stadtrat (1958)

JACQUES FREYMOND, Doctor of Literature, Director of the Graduate Institute of International Studies, Professor at the University of Geneva (1959)

DIETRICH SCHINDLER, Doctor of Laws, Professor at the University of Zurich (1961) MARJORIE DUVILLARD, Nurse (1961)

MAX PETITPIERRE, Doctor of Laws, former President of the Swiss Confederation (1961)

ADOLPHE GRAEDEL, member of the Swiss National Council from 1951 to 1963, former Secretary-General of the International Metal Workers Federation (1965)

DENISE BINDSCHEDLER-ROBERT, Doctor of Laws, Professor at the Graduate Institute of International Studies (1967)

JACQUES F. DE ROUGEMONT, Doctor of Medicine (1967)

ROGER GALLOPIN, Doctor of Laws, former Director-General (1967)

WALDEMAR JUCKER, Doctor of Laws, Secretary, Union syndicale suisse (1967)

VICTOR H. UMBRICHT, Doctor of Laws, Managing Director (1970)

PIERRE MICHELI (1971)

Honorary members: Mr. JACQUES CHENEVIERE, Honorary Vice-President;

Miss LUCIE ODIER, Honorary Vice-President; Messrs. CARL J. BURCKHARDT, PAUL CARRY, Mrs. MARGUERITE GAUTIER-VAN BERCHEM, Messrs. SAMUEL A. GONARD, EDOUARD de HALLER, PAUL LOGOZ, RODOLFO OLGIATI, FRÉDERIC SIORDET, ALFREDO VANNOTTI, ADOLF VISCHER.

Directorate: Mr. JEAN-LOUIS LE FORT, Secretary-General. Mr. RAYMOND COURVOISIER, Special Assistant to the President and Director of Operations. Mr. CLAUDE PILLOUD, Director, Department of Principles and Law. 


\section{INTERNATIONAL REVIEW OF THE RED CROSS}

NOVEMBER 1971 - No. 128

\section{CONTENTS}

\section{INTERNATIONAL COMMITTEE OF THE RED CROSS}

IN THE RED CROSS WORLD

\section{miscellaneous}

Conference of Government Experts - Geneva, 24 May-12 June 1971 (II) $\ldots \ldots \ldots \ldots \ldots \ldots \ldots, 587$

\section{External Activities:}

Africa - Republic of Vietnam - Khmer Republic Ceylon - Japan - Bolivia - Northern Ireland Middle East - Yemen Arab Republic - People's Democratic Republic of Yemen ........... 603 In Geneva :

The Emperor and Empress of Japan at the ICRC 611 Pseudo-Medical Experiments ............. 611

Preparing for the Second Session of the Conference of Government Experts ........... 613 A Tracing Service in Dacca ............. 614 The Red Cross Broadcasting Service ....... 615

Regional Training institute in West Africa ..... 617 Latin American Red Cross Regional Training Institute ......................... 619 The Empress Shôken Fund .............. 622 A New Edition of the "International Red Cross Handbook" ........................ 626

Protection of Journalists on Dangerous Missions in Areas of Armed Conflict ................. Conference on the Outlawing of Biological, Chemical and Nuclear Weapons ............ International Colloquium on Humanitarian Rules

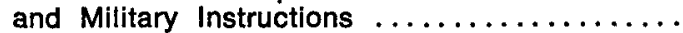
Tenth International Assembly of Amnesty International ............................ 635 Inter-Parliamentary Conference ......... 636 Child Relief .................... 637 
FRENCH EDITION

OF THE REVIEW

\section{SUPPLEMENTS}

TO THE REVIEW

SPANISH

GERMAN

INTERNATIONAL

REVIEW OF

THE RED CROSS
The French edition of this Review is issued every month under the title of Revue internationale de la Croix-Rouge. It is, in principle, identical with the English edition and may be obtained under the same conditions.

J. Patrnogic : Derecho médico internacional - Reconocimiento de la Sociedad de la Cruz Roja de Lesotho (Circular Núm. 484) - EL CICR en América Latina.

Das Verbot der Folter (II) - Anerkennung des Roten Kreuzes von Lesotho (484. Rundschreiben) - Das "Manuel du Soldat" - Das * Manuel de la CroixRouge internationale " in einer neuen Auflage.

The International Review is published each month by the International Committee of the Red Cross

7, avenue de la Paix, 1211 Geneva I, Switzerland Postal Cheque No. 121767

Annual subscription: Sw. fr. 25.- $(\$ 6)$

Single copies Sw. fr. $2.50(\$ 0.60)$

Editor: J.-G. LOSSIER

The International Committee of the Red Cross assumes responsibility only for material over its own signature. 